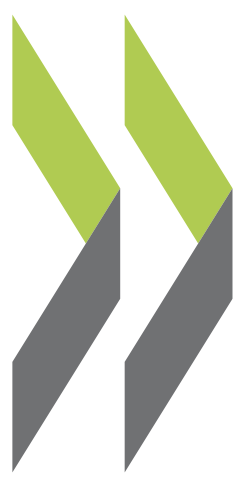

PEB Exchange, Programme on Educational Building 2007/08

$$
\begin{array}{r}
\text { Japan's Eco-school } \\
\text { Programme }
\end{array}
$$

\title{
Masayuki Mori
}

https://dx.doi.org/10.1787/077786224650 


\section{Japan's Eco-school Programme}

By Masayuki Mori, Ministry of Education, Culture, Sports, Science and Technology, Japan

Since 1997 several ministries in Japan have collaborated on an eco-school programme, which applies to both newly constructed and renovated school buildings, in an effort to make its schools more environmentally friendly.

The eco-school programme, a pilot project, was created within a framework of inter-ministerial cooperation. Currently, the following four ministries work together to implement and subsidise the programme:

- Ministry of Education, Culture, Sports, Science and Technology (MEXT).

- Ministry of Agriculture, Forestry and Fisheries.

- Ministry of Economy, Trade and Industry.

- Ministry of the Environment.

The ministries provide subsidies or grants to local education authorities that apply for the financing and can justify that their schools' design or building specifications meet the criterion defined for ecoschools.

\section{The eco-school concept}

The eco-school programme was established to promote environmentally friendly design and construction by equipping school buildings with ecological features such as photovoltaic cells, solar thermal collectors, other new energy sources, wood, roof-top gardening and rainwater recycling. In March 1996, MEXT published a report entitled "Eco-School: School Facilities with Environmental Considerations" presenting the three areas that comprise the eco-school:

- Facilities: environmentally friendly design and construction.

- Operations: intelligent and extended use.

- Education: benefits for learning.

Through the eco-school programme, the government encourages local education authorities to build and renovate environmentally friendly school buildings and to operate them in ways that are more intelligent and that extend the use of materials. The programme also promotes using environmentallyfriendly designed buildings as practical teaching materials for environmental education.

\section{Funding eco-schools}

Since the programme began, more than 600 eco-schools have been built with financial assistance from the ministries. As shown in Figure 1, the total number of government-funded eco-schools has been increasing steadily. The increase can perhaps be attributed to the growing interest of local education 
authorities in environmental friendly design and construction. In line with their interest and with today's public concern about the global environment, Japan is considering applying the concept of the ecoschool to planning school buildings in general.

\section{Figure 1}

Total number of eco-schools funded during the 1997-2006 financial years (FY)

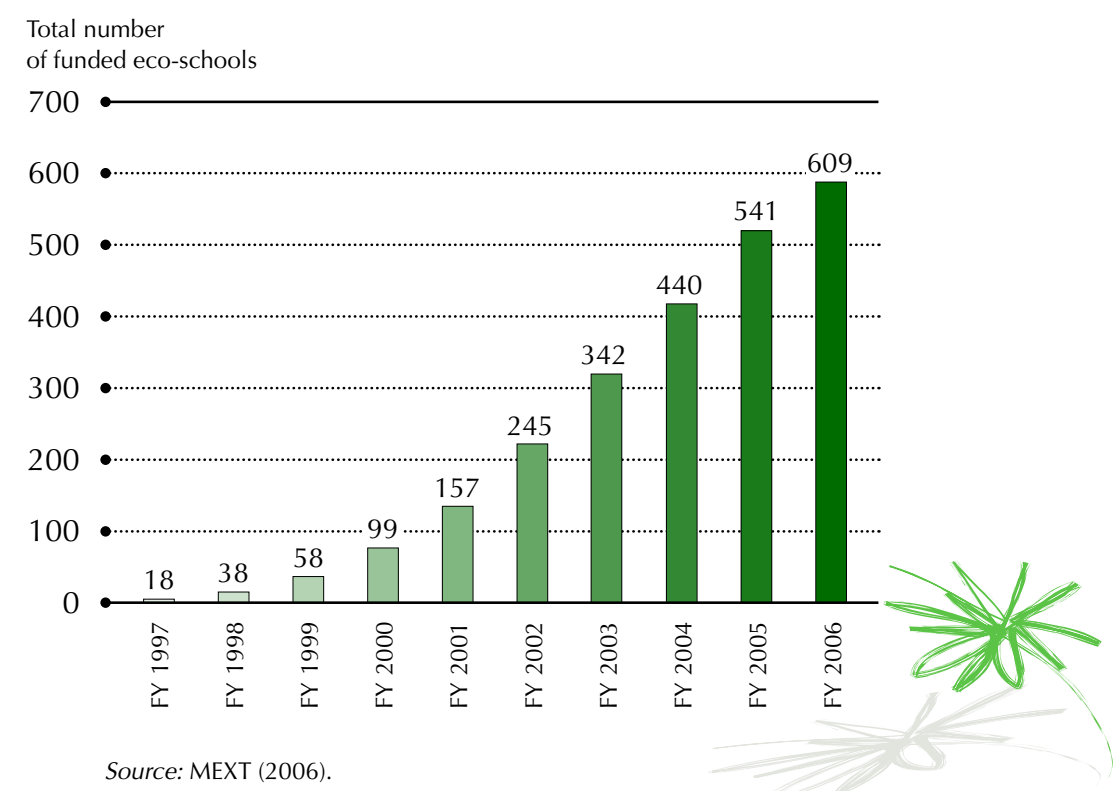

\section{A study on eco-school}

In order to expand the eco-school concept to all school buildings in the country, the government is planning a study by experts from various fields of the 600 plus eco-schools. The experts will review the schools to derive key elements covering a variety of aspects from the most successful eco-schools. They will consider how to introduce the key elements into school buildings in general, not only for new constructions or major renovations but also as concerns daily operations, maintenance, repairs, etc. An interim report is expected by the end of March 2008.

For further information, visit:

www.mext.go.jp/a_menu/shotou/zyosei/english/index.htm

or contact:

Masayuki Mori

Senior Specialist for Environmental Planning of Facilities

Facilities Planning Division

Department of Facilities Planning and Administration

Ministry of Education, Culture, Sports, Science and Technology

Tokyo, Japan

E-mail: morimasa@mext.go.jp

Note: The views expressed in this article are those of the author and do not necessarily represent the official views of the organisation to which he belongs. 


\section{ORGANISATION FOR ECONOMIC CO-OPERATION AND DEVELOPMENT}

The OECD is a unique forum where the governments of 30 democracies work together to address the economic, social and environmental challenges of globalisation. The OECD is also at the forefront of efforts to understand and to help governments respond to new developments and concerns, such as corporate governance, the information economy and the challenges of an ageing population. The Organisation provides a setting where governments can compare policy experiences, seek answers to common problems, identify good practice and work to co-ordinate domestic and international policies.

The OECD member countries are: Australia, Austria, Belgium, Canada, the Czech Republic, Denmark, Finland, France, Germany, Greece, Hungary, Iceland, Ireland, Italy, Japan, Korea, Luxembourg, Mexico, the Netherlands, New Zealand, Norway, Poland, Portugal, the Slovak Republic, Spain, Sweden, Switzerland, Turkey, the United Kingdom and the United States. The Commission of the European Communities takes part in the work of the OECD.

OECD Publishing disseminates widely the results of the Organisation's statistics gathering and research on economic, social and environmental issues, as well as the conventions, guidelines and standards agreed by its members.

This work is published on the responsibility of the Secretary-General of the OECD. The opinions expressed and arguments employed herein do not necessarily reflect the official views of the Organisation or of the governments of its member countries.

No reproduction, copy, transmission or translation of this publication may be made without written permission. Applications should be sent to OECD Publishing rights@oecd.org or by fax 331452499 30. Permission to photocopy a portion of this work should be addressed to the Centre français d'exploitation du droit de copie (CFC), 20, rue des Grands-Augustins, 75006 Paris, France, fax 331463467 19, contact@cfcopies.com or (for US only) to Copyright Clearance Center (CCC), 222 Rosewood Drive Danvers, MA 01923, USA, fax 1978646 8600, info@copyright.com. 